\title{
Neoproterozoic chemostratigraphy and correlation of the Port Askaig glaciation, Dalradian Supergroup of Scotland
}

\author{
M. D. BRASIER ${ }^{1} \&$ G. SHIELDS ${ }^{2}$ \\ ${ }^{1}$ Department of Earth Sciences, Parks Road, Oxford OX1 3PR, UK (e-mail: martinb@earth.ox.ac.uk) \\ ${ }^{2}$ Ottawa-Carleton Geoscience Centre, University of Ottawa, Ottawa, Ontario K1N 6N5, Canada
}

\begin{abstract}
The $\delta^{13} \mathrm{C}$ of preglacial carbonates beneath the glaciogenic Port Askaig Formation falls from $+5 \%$ to negative values, while least-altered ${ }^{87} \mathrm{Sr} /{ }^{86} \mathrm{Sr}$ values are close to 0.7067 . Postglacial "cap carbonates' of the Bonahaven Formation begin with negative $\delta^{13} \mathrm{C}_{\text {carb }}$ values, jumping sharply to $+11.7 \%$ near the top, which we correlate with excursions above the Elbobreen-Wilsonbreen glaciations of Svalbard and putative Sturtian (not Varanger) glaciations elsewhere, dated at $c$. 720 Ma. Much of the succeeding Terminal Neoproterozoic is missing in NE Svalbard and East Greenland, raising doubts about their use for global $\mathrm{Sr}$ and $\mathrm{C}$ isotope curves in the Neoproterozoic.
\end{abstract}

Keywords: Neoproterozoic, Dalradian, glaciation, chemostratigraphy.

The later Neoproterozoic arguably contains some of the most extreme climatic fluctuations in Earth history, from snowball earth to greenhouse conditions, with important implications for biosphere evolution (e.g. Hoffman et al. 1998). At present, however, there is no agreement on the number or extent of these glaciations: some recognize four, none of which were global (Kaufman et al. 1997) while others accept only two global glaciations (Kennedy et al. 1998). Distinction between these scenarios is hindered by the paucity of reliable chronometric constraints and biostratigraphic data (e.g. Brasier et al. 2000). Associated carbonates reveal large swings in $\delta^{13} \mathrm{C}$ values from highly positive values in the interglacials, falling to negative values during and/or following the glacial intervals, and these can be used to characterize particular time intervals (e.g. Knoll et al. 1986; Brasier et al. 1996; Kaufman et al. 1997; Kennedy et al. 1998), although they cannot provide unique signatures.

A major concern for Neoproterozoic stratigraphy, therefore, is completeness of the geological record: where and how long are the large time gaps? Without this information, it is difficult to establish a reliable chemostratigraphic or biostratigraphic scale. Strontium isotopes in carbonates may help here, if they are well-preserved, because there is evidence for a long-term trend towards more radiogenic ${ }^{87} \mathrm{Sr} /{ }^{86} \mathrm{Sr}$ values between $c .800$ and $500 \mathrm{Ma}$ (e.g. Derry et al. 1989, 1992; Brasier et al. 1996; Shields 1999).

The Dalradian Supergroup of Scotland (Fig. 1) is one of the thickest $(<25 \mathrm{~km})$ and potentially one of the most complete Neoproterozoic-Cambrian successions to be found anywhere. It contains an important U-Pb zircon age of $595 \pm 4 \mathrm{Ma}$ from a submarine keratophyre in the Tayvallich subgroup (Halliday et al. 1989), which lies up to $12 \mathrm{~km}$ above the Port Askaig Tillite (Harris et al. 1994). It has also been compared with the Laurentian successions of NE Svalbard and East Greenland, which have played a conspicuous role in the development of reference curves for carbon and strontium isotope stratigraphy in the Terminal Neoproterozoic (Knoll et al. 1986; Derry et al. 1989, 1992; Kaufman et al. 1997; Jacobsen \& Kaufman 1999). The Dalradian succession differs from these in having a greatly expanded thickness of post-glacial Neoproterozoic sediments plus volcanics (Fig. 1; Soper 1994; Fairchild \& Hambrey 1995).
In this paper, we outline the carbon and strontium isotopic character of carbonates in the Dalradian Supergroup of Scotland with the aim of testing their potential for correlation of the Port Askaig glaciation with those in NE Svalbard and elsewhere.

\section{Geological setting}

Sediments and metasediments of the Dalradian Supergroup are traceable along strike from NW Ireland to NE Scotland (Anderton 1985; Harris et al. 1994). Some $7 \mathrm{~km}$ of arkosic clastics of the Grampian Group, at the base of the supergroup, have been interpreted as either synrift or foreland basin deposits, laid down before c. $806 \mathrm{Ma}$ (e.g. Soper 1994; Prave 1999a). The succeeding Appin Group (Fig. 1; c. 4 km thick) consists largely of sedimentary cycles in which argillites (now mainly phyllite or schist) pass up into shallower water quartzite or dark platformal limestones.

The Port Askaig Tillite $(<750 \mathrm{~m})$ at the base of the Argyll Group, consists largely of glaciomarine facies (Eyles \& Eyles 1983). Abundant dolomitic clasts within diamictites near the base suggest local erosion of underlying dolostones, while nordmarkite clasts in feldspathic sandstone diamictites near the top indicate erosion of crystalline basement to the south (Anderton 1980). Deglaciation was followed by deposition of a thick 'cap carbonate' (the Bonahaven Formation, <295 m) which, along with associated quartz arenites, was laid down in peritidal to shallow subtidal conditions (Fairchild 1980). The succeeding Jura Quartzite, which may be up to $5 \mathrm{~km}$ thick, was deposited under tidal and storm-dominated shelf conditions in fault-bounded basins, during which increasing subsidence and depositional rates were broadly kept in balance (Anderton 1985).

Black shales of the Jura Slate and Easdale Slate, and turbidites plus mass flow deposits of the Scarba/Benderloch Conglomerate, together may indicate a phase of rapid basin deepening in response to major fault block movements (Anderton 1985). The upward passage from the Easdale Slate to the Degnish Limestone is gradational, and may indicate a progressive shallowing. Filling of this basin during deposition 


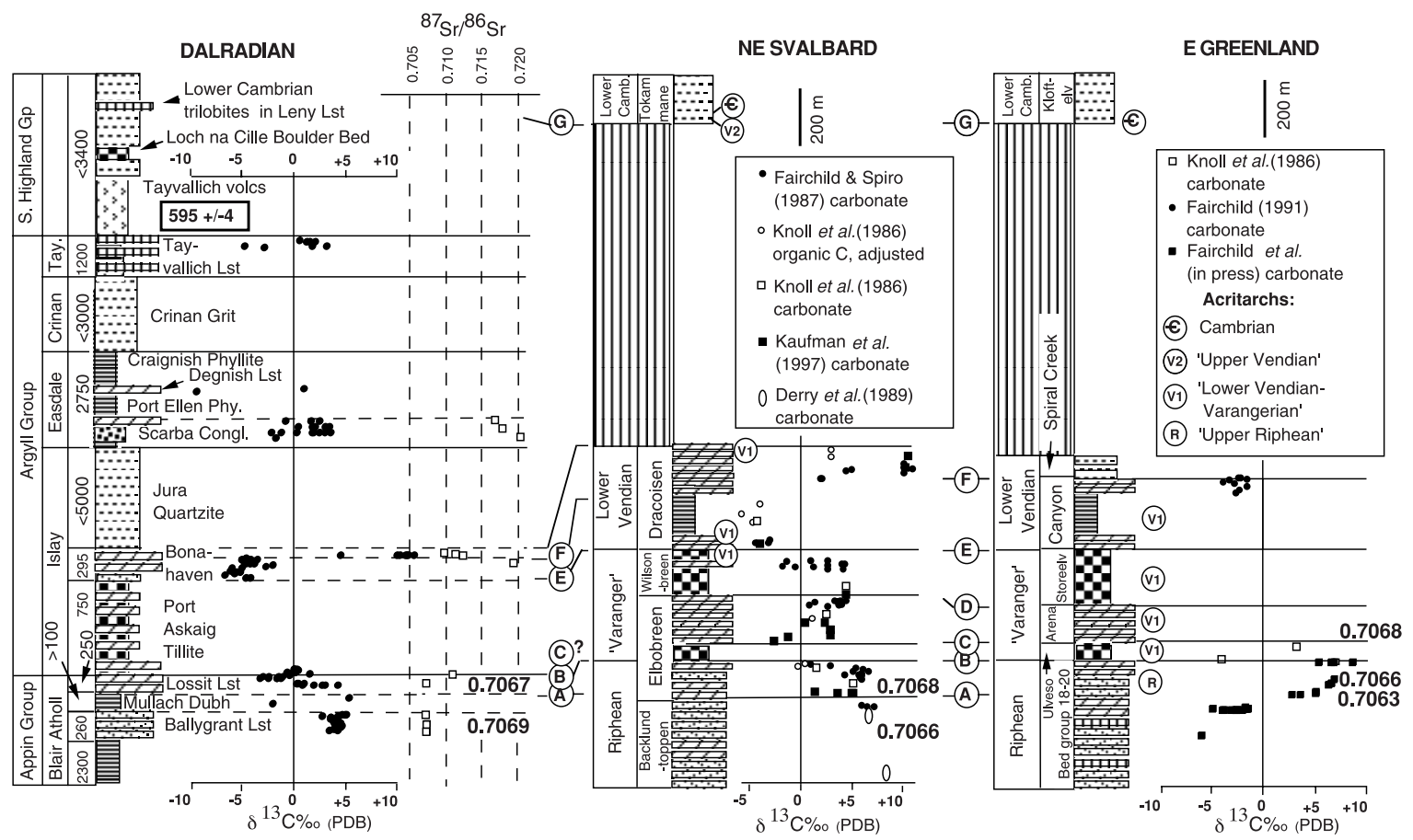

Fig. 1. Summary of Dalradian stratigraphy showing the carbon (black dots) and strontium (white squares) isotope data from Islay, Jura and Argyll obtained in this paper, compared with that from NE Svalbard and East Greenland (after Knoll et al. 1986; Derry et al. 1989, 1992; Kaufman et al. 1997; Fairchild 1991, Fairchild et al. in press). A-F, event stratigraphic tie lines between NE Svalbard and East Greenland (after Fairchild \& Hambrey 1995) and Scotland (suggested herein): A, deepening event in pre-glacial carbonate platform; B, erosional to conformable sequence boundary at base of lower glacial deposits; C, rapid deglaciation and transgression; D, erosional to conformable sequence boundary at base of upper glacial deposits; E, rapid deglaciation and transgression; F, highstand, regressive facies; G, Lower Cambrian transgression. Acritarch assemblages from Svalbard and Greenland after sources in Knoll \& Swett (1987).

of the Craignish Phyllites is indicated by evidence for evaporites (Anderton 1985). A second major cycle of fault-bound subsidence produced submarine fans of the Crinan Grit and turbiditic carbonates of the Tayvallich Limestone. Continued subsidence led to deposition of thick turbiditic sandstones of the Southern Highland Group, including localized mafic extrusives such as the Tayvallich Volcanics (Harris et al. 1994). The Leny Limestone of Perthshire, which comprises thin bedded turbiditic carbonates, arguably belongs to the uppermost part of this group (Tanner 1995).

\section{Age of the Dalradian}

Correlation of the Dalradian is hampered by the rarity of biostratigraphic markers. The trilobite Pagetides sp. provides a late early Cambrian age for the Leny Limestone at the top of the succession (Pringle 1940). A post-Varanger age for the Argyll Group has been inferred on the basis of putative metazoan trace fossils. Re-examination by us of Neonereites markings reported by Brasier \& McIlroy (1998) shows, however, that these could arguably have been produced by sedimentary processes, while carbonate clasts at Benderloch reveal that the Cloudina-like forms of Conway Morris (1998) may be parts of composite coated grains or oncolites. The Precambrian-Cambrian boundary (c. $543 \mathrm{Ma}$; Grotzinger et al. 1995) must, however, lie somewhere beneath the Leny Limestone and above lavas dated at $595 \pm 4 \mathrm{Ma}$ (Halliday et al. 1989).

Until recently it has been assumed, on the basis of lithostratigraphy, that the Port Askaig Tillite correlates with the twin Varanger tillites of Norway, the Elbobreen and
Wilsonbreen tillites of NE Svalbard, plus the Ulveso and Storeelv tillites of East Greenland (e.g. Soper 1994; Harris et al. 1994). These, in turn, have been correlated by lithostratigraphy with the Marinoan glaciation of south and central Australia, and by carbon isotope stratigraphy with the Icebrook glaciation of NW Canada, estimated at c. 590 $564 \mathrm{Ma}$ old (e.g. Kaufman et al. 1997; Saylor et al. 1998). Kennedy et al. (1998) have argued, however, that the upper 'Varanger' glacial in Norway, Svalbard and Greenland is Marinoan, whereas the lower 'Varanger' glacial is Sturtian (c. 723 Ma, see Brasier et al. 2000). Prave (1999a) has gone further and suggested a wholly Sturtian age for the Port Askaig glaciation, since it lies up to $12 \mathrm{~km}$ below strata dated at $595 \mathrm{Ma}$ (Fig. 1). This would mean that Marinoan/younger Varanger glaciations could lie higher in the Dalradian, at the level of the Loch na Cille Boulder Bed (Prave 1999a) and/or glacially-influenced sediments in the Macduff Slates (see Stoker et al. 1999), both in the Southern Highland Group (Fig. 1).

\section{Neoproterozoic-Cambrian isotope stratigraphy}

A decade of intensive study into carbon and strontium isotopes from carbonate rocks of the Neoproterozoic-Cambrian means that chemostratigraphy can provide a way to test the relative age of the Port Askaig Tillite. Most important are reference sections in which the stratigraphic succession is unambiguous, the major sedimentary breaks are acknowledged, the palaeontological datum points (including the Precambrian-Cambrian boundary) are clear, and the carbonates contain well-preserved $\delta^{13} \mathrm{C}$ and (most importantly) ${ }^{87} \mathrm{Sr} /{ }^{86} \mathrm{Sr}$ signatures. In our view, 
the successions of SW Mongolia and Siberia (Brasier et al. 1996), the Mackenzie Mountains of Canada (Kaufman et al. 1997), the Kalahari craton of Namibia (Grotzinger et al. 1995) and Oman (Brasier et al. 2000) must play key roles. Unfortunately, the ages of Neoproterozoic successions from NE Svalbard, East Greenland, and the Otavi craton of Namibia remain controversial (see Kaufman et al. 1997; Kennedy et al. 1998; Jacobsen \& Kaufman 1999).

We infer that the older glaciations (including the Rapitan of Canada, Sturtian of Australia and Maikhan Uul of Mongolia) are bracketed by ${ }^{87} \mathrm{Sr} /{ }^{86} \mathrm{Sr}$ signatures in carbonates of c. 0.7067 , and followed by extremely positive $\delta^{13} \mathrm{C}$ values of $>+10 \%$ o that are otherwise unmatched in the last $1000 \mathrm{Ma}$. The younger glaciations (including the Icebrook of Canada, Marinoan of Australia and Fiq of Oman) are followed by ${ }^{87} \mathrm{Sr} /{ }^{86} \mathrm{Sr}$ values that rise rapidly from $c .0 .7072$ to 0.7084 and by $\delta^{13} \mathrm{C}$ values that do not rise above $+8 \%$. The latter interval is also characterized by the Pertatataka acritarch microflora, and this in turn is followed by unequivocal Ediacara and Cloudina biota (e.g. Brasier et al. 2000).

120 samples were collected for chemostratigraphy from carbonate outcrops in the Dalradian of Islay, Jura and the nearby Argyll mainland, where the metamorphic grade is relatively low and the microfabrics are well-preserved (e.g. Fairchild 1985). All samples were thin-sectioned, stained with potassium ferricyanide and alizarin red-S, and studied microscopically for evidence of major diagenetic (e.g. ferroan) carbonate phases. Where available, fine-grained carbonate (mainly comprising micritic or microsparitic mudstone) was selectively drilled from the most homogeneous regions of the rock slice, to form a powder for oxygen and carbon isotopic analysis using the techniques described in Brasier et al. (1996). 22 samples were selected on the basis of sample homogeneity and stable isotope values, for strontium isotope analysis in Strasbourg. Sample chips were dissolved during 24 hours in 100\% glacial acetic acid, with distilled water added dropwise until reaction was evident. After standard $\mathrm{Sr}$ concentration procedures, analysis was carried out on a VG Sector multicollector in dynamic mode; the standard NBS 987 averaged $0.710286(n=3)$ over the period of measurement (cf. 0.710201, Fairchild et al. in press; 0.710241, Derry et al. 1989, 1992; and 710254, Brasier et al. 1996). Data discussed herein are normalized to an NBS 987 value of 0.71025 . The same leachates were evaporated and analysed as $1 \mathrm{M} \mathrm{HNO}_{3}$ solutions for their trace element chemistries using ICP-AES $(\mathrm{Ca}, \mathrm{Mg}$, $\mathrm{Sr}, \mathrm{Ba}, \mathrm{Mn}, \mathrm{Fe}, \mathrm{K}, \mathrm{Na}$ ) and ICP-MS (Rb, $\mathrm{Sr}$ ). Rb concentrations were too low for ${ }^{87} \mathrm{Rb}$ decay to alter significantly the limestone ${ }^{87} \mathrm{Sr} /{ }^{86} \mathrm{Sr}$ data.

\section{Results}

A summary of our chemostratigraphic data from the Dalradian (Fig. 1, Table 1) indicates a fall in maximum $\delta^{13} \mathrm{C}$ values from $c .+5 \%$ in the Ballygrant Limestone and Mullach Dubh Phyllite, towards negative values in the Persabus dolostones of the Lossit Formation, beneath the Port Askaig Tillite. Although this trend appears to have been accentuated by diagenesis, particularly in ferroan dolostones of the Mull of Oa section where $\delta^{18} \mathrm{O}$ values fall below $-9 \%$, it is also seen in shallow water non-ferroan dolostones from Loch Lossit and Keills in which $\delta^{18} \mathrm{O}$ values are $>-5 \%$. This suggests that the negative trend beneath the Port Askaig glaciation could reflect a global change in seawater chemistry. Dolostone interbeds and diamictites within the lower part of the Port Askaig Tillite have carbon isotopic values close to those from the underlying Lossit dolostones, consistent with their derivation from these beds by glacial erosion.

Members 1 and 3 of the Bonahaven Formation 'cap carbonate' (Fig. 1) show a fall in $\delta^{13} \mathrm{C}$ of more than $2 \%$. Oxygen isotope values are comparable with those from the underlying Port Askaig Tillite and Lossit Formation. Although ferroan dolomicrite fabrics and strong $\mathrm{C}-\mathrm{O}$ covariance $\left(r^{2}=0.7\right.$ to 0.9$)$ may be taken to suggest that the more negative carbon isotopic signals have been reset along a mixing line, negative values are also found within less-altered non-ferroan dolomite and calcitic limestone components. The dramatic rise to $\delta^{13} \mathrm{C}$ values around $+11.7 \%$ in Member 4 (Fig. 1) is unaccompanied by any major shift in oxygen isotopes, but does mark a switch from $\mathrm{Fe}$ - and Mn-rich to Fe- and Mn-poor dolomites. This is one of the most extreme carbon isotopic swings in the geological record and therefore provides a potential marker for correlation. A single sample at the top of Member 4 has lower values $(+4.5 \%)$.

Carbon isotopic values from carbonates of the Argyll Group (i.e., the Scarba Conglomerate, Port Ellen Phyllite, Degnish Limestone and Tayvallich Limestone) reveal a relatively large spread (Fig. 1, Table 1) which may, in part, reflect the influence of allochthonous carbonate sources. The $\delta^{13} \mathrm{C}$ maxima do not much exceed $+3 \%$, however, and this may be close to seawater values for the interval.

Strontium isotopic ratios of $>0.7096(n=10)$ in the Argyll Group limestones and dolostones are accompanied by positive correlations between ${ }^{87} \mathrm{Sr} /{ }^{86} \mathrm{Sr}$ and $\mathrm{Mn} / \mathrm{Sr}$ (Table 2), indicating diagenetic alteration of $\mathrm{Sr}$ isotope signals during diagenesis (cf. Brasier et al. 1996). Appin Group limestones are better preserved, having high $\mathrm{Sr}$ concentrations (>1000 ppm) and low $\mathrm{Mn} / \mathrm{Sr}$ ratios $(<0.2)$, yielding values of between 0.70691 and $0.70725(n=6)$ for the Ballygrant Limestone, falling to between 0.70669 and 0.70720 for the Persabus Member of the Lossit formation, a few tens of metres beneath the Port Askaig Tillite (Fig. 1; Table 2). The lowest ${ }^{87} \mathrm{Sr} /{ }^{86} \mathrm{Sr}$ ratios correspond to samples with the lowest $\mathrm{Mn} / \mathrm{Sr}$ ratios $(<0.1)$, implying that these values provide maximum constraints on seawater ${ }^{87} \mathrm{Sr} /{ }^{86} \mathrm{Sr}$.

\section{Discussion}

Both the carbon and strontium isotope results are consistent with previously suggested comparisons between the Appin Group to Bonahaven Formation of the Scottish Dalradian, the Backlundtoppen to Dracoisen formations of NE Svalbard, and bed groups 18-20 up to the Spiral Creek Formation of East Greenland (Fig. 1; e.g., Fairchild 1989; Fairchild \& Hambrey 1995; Soper 1994). In each area, carbonates beneath the lower glacial unit yield low, least-altered ${ }^{87} \mathrm{Sr} /{ }^{86} \mathrm{Sr}$ values close to 0.7067 (Fig. 1), while carbonates above the upper glacial unit, in the Bonahaven and Dracoisen formations contain a distinctive carbon isotopic marker with values of $+11 \%$. Above this in Scotland, there is evidence for increasing platform instability and rapid subsidence, followed by marked deepening and volcanic activity. Conversely, in NE Svalbard and East Greenland, both acritarchs and sedimentology suggest several prolonged breaks (e.g. Knoll \& Swett 1987; Fairchild 1991) implying that this part of the Laurentian margin experienced non-deposition or erosion.

Carbon isotopic values of $>+10 \%$ provide a distinctive marker for the interval between the Sturtian and Marinoan/ Varanger glaciations (Brasier et al. 1996; Jacobsen \& Kaufman 1999). Hence $\delta^{13} \mathrm{C}$ values as high as $+11.7 \%$ in the Bonahaven Formation, when taken together with ${ }^{87} \mathrm{Sr} /{ }^{86} \mathrm{Sr}$ ratios as low as 0.7067 beneath the Port Askaig Tillite, suggest correlation with the older, Sturtian/Rapitan glaciations rather than with 
Table 1. Carbon and oxygen isotope data from Dalradian carbonates

\begin{tabular}{|c|c|c|c|c|c|c|c|c|c|}
\hline Sample & Height & Lithology & $\delta^{13} \mathrm{C}$ & $\delta^{18} \mathrm{O}$ & Sample & Height & Lithology & $\delta^{13} \mathrm{C}$ & $\delta^{18} \mathrm{O}$ \\
\hline Tayvillich Lst: & & & & & Pt Askaig Fm: & & & & \\
\hline Ben 8 & 4742 & fds qtz py & 0.5 & -4.9 & LL1 & 500 & fdms qtz & -0.7 & -10.3 \\
\hline Ben 7 & 4738 & fds qtz py & 1.5 & -4.5 & LL3 & 500 & $\mathrm{dm}$ dms qtz & -0.1 & -8.9 \\
\hline Ben 6 & 4733 & fds qtz & 2.0 & -1.2 & LL2 & 499 & $\mathrm{dm}$ dms qtz & 0.3 & -8.2 \\
\hline Ben 5 & 4732 & fds qtz py & 1.3 & -1.9 & LL4 & 497 & dms & 0.1 & -8.8 \\
\hline Ben 4 & 4692 & fds qtz py & 3.1 & -4.6 & LL5 & 495 & qtz dms mx & 0.2 & -7.5 \\
\hline Ben 3 & 4691 & cs ds qtz py & 1.8 & -7.3 & Lossit Fm: & & & & \\
\hline Ben 2 & 4690 & fds qtz py & -4.8 & -4.6 & LL6 & 492 & fdms qtz & 0.4 & -6.8 \\
\hline Ben 1 & 4687 & fds qtz py & -2.8 & -5.2 & LL7 & 482 & $\mathrm{dm} \mathrm{qtz}$ & 1.5 & -4.5 \\
\hline Degnish Lst: & & & & & LL9 & 472 & fcs qtz & -0.4 & -0.8 \\
\hline Deg 2 & 3666 & fcs qtz & 0.9 & -15.8 & LL8 & 462 & $\mathrm{dms} d \mathrm{~s}$ & -1.7 & -6.2 \\
\hline Deg 1 & 3665 & qtz fcs & -9.5 & -14.5 & $\mathrm{OA} 2$ & 459 & fdms qtz mic & -1.1 & -11.1 \\
\hline Scarba Congl.: & & & & & OA3 & 458 & fdms qtz & -1.4 & -11.2 \\
\hline Kin 1 & 2665 & qtz phy dm & 1.7 & -12.3 & OA3a & 457 & fdms qtz & -3.0 & -12.3 \\
\hline Kin 2 & 2665 & qtz phy fdm py & -0.8 & -14.4 & OA4 & 456 & fdms qtz & -2.4 & -12.1 \\
\hline Kin 3 & 2664 & fdm qtz & 2.5 & -14.8 & OA5 & 455 & fds fdms & -1.7 & -12.0 \\
\hline Bend 3a1 & 2614 & fcs ic qtz & 3.5 & -14.2 & OA6 & 454 & fdms ds & -1.6 & -10.7 \\
\hline Bend $3 \mathrm{a} 2$ & 2614 & fcs ic qtz & 3.0 & -14.3 & OA 7 & 453 & dms qtz & -1.3 & -10.0 \\
\hline Bend $3 b$ & 2614 & qtz fes ic & 1.8 & -13.8 & OA8 & 452 & fdm qtz mic & -2.5 & -9.3 \\
\hline Bend $3 \mathrm{c} 1$ & 2614 & qtz fes & 0.4 & -13.6 & OA9 & 451 & fdm fdms mic & -3.4 & -9.5 \\
\hline Bend $3 c 2$ & 2614 & qtz fes onc & 2.0 & -13.9 & Pe 9 & 399 & $\mathrm{dm}$ fds & 0.2 & -5.2 \\
\hline Bend 2a & 2564 & qtz phy fcs & -2.2 & -9.5 & Pe 8 & 397 & $\mathrm{dm}$ fds & 0.4 & -4.7 \\
\hline Bend $2 b$ & 2564 & fes onc & 3.5 & -13.3 & $\mathrm{Pe} 7$ & 395 & $\mathrm{dm}$ ds & 0.9 & -5.5 \\
\hline Bend $2 \mathrm{c}$ & 2564 & qtz fcs & 1.9 & -12.2 & Pe 6 & 393 & $\mathrm{dm}$ fdm ds & 0.8 & -6.6 \\
\hline Bend 2d & 2564 & cs fes & 0.3 & -12.1 & Pe 5 & 391 & cs qtz & 3.0 & -4.2 \\
\hline Bend 2e & 2564 & qtz phy fcs & 3.0 & -15.0 & $\mathrm{Pe} 4$ & 389 & cs qtz & 2.8 & -5.5 \\
\hline Bend 2f & 2564 & $\mathrm{qtz} \mathrm{fcm}$ & -1.2 & -11.8 & Pe 3 & 387 & $\mathrm{cms}$ qtz & 1.9 & -10.2 \\
\hline Bend $2 \mathrm{~g}$ & 2564 & fes onc cs & 2.4 & -14.1 & Pe 1 & 383 & $\mathrm{cms}$ qtz & 4.3 & -6.6 \\
\hline Bend $2 \mathrm{~h}$ & 2564 & cs onc fes & 1.7 & -14.4 & Mullach Dubh: & & & & \\
\hline Bend 1 & 2514 & fcs qtz & -1.8 & -10.3 & OA10 & 234 & fcms cs & 5.3 & -12.3 \\
\hline Bonahaven Fm: & & & & & OA11 & 233 & dms qtz & -2.0 & -9.4 \\
\hline Mem 4 Bd 16 & 1513 & $\mathrm{cms}$ fcm qtz & 4.5 & -5.9 & Ballygrant Lst: & & & & \\
\hline Bd 17 & 1512 & dms qtz & 11.0 & -9.9 & $\mathrm{Ba} 28$ & 133 & cms cs ic & 5.0 & -7.4 \\
\hline Bd 18 & 1511 & dms ds py & 10.8 & -9.1 & Ba 27 & 132 & $\mathrm{cms}$ cs ic mic & 4.9 & -7.1 \\
\hline Bd 19 & 1510 & dms cs qtz py & 11.7 & -9.7 & $\mathrm{Ba} 26$ & 128 & $\mathrm{cms} \mathrm{cs} \mathrm{ic}$ & 4.6 & -7.2 \\
\hline $\mathrm{Bd} 13$ & 1508 & dms qtz py & 10.3 & -10.5 & $\mathrm{Ba} 25$ & 123 & $\mathrm{cms} \mathrm{cs}$ ic & 4.3 & -7.3 \\
\hline Bd 14 & 1506 & dm cs qtz py & 11.0 & -10.1 & $\mathrm{Ba} 24$ & 118 & $\mathrm{cms} \mathrm{ds}$ & 2.7 & -10.3 \\
\hline Bd 15 & 1505 & dm qtz py & 10.0 & -10.8 & $\mathrm{Ba} 23$ & 113 & $\mathrm{cms} \mathrm{ds}$ & 3.6 & -6.3 \\
\hline Mem 3 Bd 12 & 1480 & fdm qtz gy? & -4.7 & -11.5 & $\mathrm{Ba} 22$ & 108 & $\mathrm{dms} d s$ & 3.5 & -4.2 \\
\hline Bd 11 & 1475 & fdm qtz & -5.0 & -11.7 & Ba 21 & 103 & $\mathrm{~cm} \mathrm{cms} \mathrm{ds}$ & 3.6 & -7.1 \\
\hline Bd 10 & 1470 & dm cs qtz py & -4.5 & -11.6 & Ba 20 & 98 & $\mathrm{~cm} \mathrm{dm} \mathrm{ic}$ & 4.0 & -6.9 \\
\hline Bd 9 & 1469 & dms cs qtz & -4.2 & -10.5 & Ва 19 & 93 & $\mathrm{~cm} \mathrm{dm} \mathrm{ic}$ & 3.7 & -7.6 \\
\hline Bd 8 & 1468 & fdm cs qtz & -3.5 & -7.4 & Ba 18 & 88 & $\mathrm{cms} \mathrm{dm} \mathrm{ic} \mathrm{oo}$ & 4.3 & -9.5 \\
\hline Bd 7 & 1456 & fdm qtz py & -3.8 & -8.9 & Ba 17 & 83 & $\mathrm{~cm} \mathrm{dm} \mathrm{ic}$ & 3.9 & -6.1 \\
\hline Bd 6 & 1455 & dm fdms qtz py & -4.5 & -11.0 & $\mathrm{Ba} 16$ & 78 & $\mathrm{~cm} \mathrm{dm} \mathrm{ic}$ & 4.1 & -7.7 \\
\hline Bd 5 & 1450 & $\mathrm{dm}$ fdm qtz & -4.7 & -10.4 & Ba 15 & 73 & $\mathrm{~cm} \mathrm{cms}$ & 3.9 & -9.5 \\
\hline $\mathrm{Bd} 4$ & 1447 & $\mathrm{dm}$ fdm qtz & -4.6 & -9.9 & $\mathrm{Ba} 1$ & 63 & $\mathrm{~cm} \mathrm{dm} \mathrm{ic}$ & 4.5 & -5.6 \\
\hline $\mathrm{Bd} 3$ & 1442 & qtz fdm py & -4.7 & -10.3 & Ba 2 & 58 & $\mathrm{~cm} \mathrm{cms}$ & 4.2 & -8.0 \\
\hline $\mathrm{Bd} 2$ & 1439 & dm qtz py & -3.8 & -9.0 & $\mathrm{Ba} 3$ & 53 & $\mathrm{cms} \mathrm{dm} \mathrm{ic}$ & 4.4 & -7.3 \\
\hline Bd 1 & 1437 & fdm qtz py & -4.2 & -9.9 & $\mathrm{Ba} 4$ & 48 & $\mathrm{~cm} \mathrm{dm} \mathrm{ic}$ & 4.3 & -7.6 \\
\hline Bun 1 & 1419 & $\mathrm{dm}$ fdm qtz py & -2.0 & -7.3 & Ba 5 & 43 & $\mathrm{~cm} \mathrm{dm} \mathrm{ic}$ & 4.0 & -6.1 \\
\hline Bun 2 & 1409 & $\mathrm{dm}$ fdm qtz py & -2.8 & -8.1 & Ва 6 & 38 & $\mathrm{~cm} \mathrm{dm} \mathrm{ic}$ & 4.6 & -6.0 \\
\hline Bun 3 & 1397 & dm fdm qtz py & -5.1 & -10.6 & $\mathrm{Ba} 7$ & 34 & $\mathrm{~cm} \mathrm{dm} \mathrm{ic}$ & 4.4 & -6.0 \\
\hline Bun 4 & 1393 & dm cs py & -6.1 & -10.9 & Ba 8 & 29 & $\mathrm{~cm} \mathrm{dm} \mathrm{ic}$ & 4.5 & -6.8 \\
\hline Bun 5 & 1378 & dm fdm qtz py & -6.2 & -10.4 & Ва 9 & 24 & $\mathrm{cms}$ oo & 4.4 & -8.3 \\
\hline Bun 6 & 1364 & dm fdm qtz py & -5.2 & -9.4 & Ba 10 & 19 & $\mathrm{cms}$ oo & 4.4 & -6.2 \\
\hline Bun 7 & 1362 & fdm oo fdm qtz & -5.6 & -10.8 & Ba 11 & 15 & $\mathrm{~cm} \mathrm{dm} \mathrm{ic}$ & 4.0 & -6.3 \\
\hline Bun 8 & 1359 & fdms dms cs & -5.9 & -11.2 & Ba 12 & 10 & $\mathrm{~cm} \mathrm{dm} \mathrm{ic}$ & 3.9 & -7.3 \\
\hline Bun 11 & 1354 & fdm qtz py & -5.8 & -11.5 & Ba 13 & 5 & $\mathrm{~cm} \mathrm{cms}$ & 3.4 & -10.0 \\
\hline Bun 12 & 1344 & $\mathrm{dm}$ fdm qtz & -6.7 & -11.2 & Ba 14 & 0 & $\mathrm{cms} \mathrm{dm}$ ic & 4.3 & -6.8 \\
\hline Mem 1 Bun 10 & 1314 & dms qtz & -4.6 & -12.0 & & & & & \\
\hline Bun 9 & 1312 & dms sph & -4.3 & -10.5 & & & & & \\
\hline
\end{tabular}

All heights (in metres) are referenced to zero at the base of the Ballygrant Limestone. Localities: Ballygrant Lst (Ba 1-28, NR 395658); Mullach Dubh Phyllite (OA 10, 280418; OA 11, NR 281421); Lossit Lst (Pe 1-9, NR 422687; LL6-9, NR 414647; OA 1-9, NR 282413); Port Askaig Tillite (LL1-5, NR 414647); Bonahaven Fm (Bun 1-11, NR 423733; Bd 1-19, 407793); clasts in Scarba/Benderloch Conglomerate (Bend 1, NM 902380; Bend 2, NM 904385; Bend 3, NM 906386); top of Scarba Congl./base of Port Ellen Phyllite (Kin 1-3, NR 706992); Degnish Lst (Deg 1, NM 777123, Deg 2 float, NM 783123); Tayvallich Lst (Ben 1-8, NR 867713). Mem, member. Lithologies: c, calcitic; d, dolomitic; f, ferroan; gy, gypsum pseudomorphs; ic, carbonate intraclasts; m, micrite; mic, mica flakes; ms, microspar; onc, oncolitic; oo, oolitic; phy, phyllitic; py, pyritic; qtz, quartz sand/silt; s, spar; sph, phengite spherules. 
Table 2. Strontium isotopes and analytical data obtained from selected Dalradian carbonates (see Table 1)

\begin{tabular}{lrrrrrrrr}
\hline Sample & Insol. residue & ${ }^{87} \mathrm{Rb} /{ }^{86} \mathrm{Sr}$ & ${ }^{87} \mathrm{Sr} /{ }^{86} \mathrm{Sr}$ & $\mathrm{Sr} / \mathrm{Ca}$ & $\mathrm{K} / \mathrm{Ca}$ & $\mathrm{Mg} / \mathrm{Ca}$ & $\mathrm{Mn} / \mathrm{Sr}$ & $\mathrm{Fe} / \mathrm{Sr}$ \\
\hline Bend 3a2 & & & & & & & & \\
Bend 2 g & $33.6 \%$ & $<0.00010$ & 0.716600 & 0.00402 & 0.0006 & 0.01030 & 1.39 & 4.67 \\
Bend 2H & $4.5 \%$ & $<0.00010$ & 0.717561 & 0.00289 & 0.0035 & 0.00888 & 1.02 & 5.16 \\
Bd 19 & $4.2 \%$ & $<0.00010$ & 0.720105 & 0.00694 & 0.0003 & 0.03460 & 1.25 & 3.76 \\
Bd 18 & $2.0 \%$ & 0.00109 & 0.709573 & 0.00101 & 0.0028 & 0.318 & 0.45 & 2.77 \\
Bd 17 & $22.0 \%$ & 0.00239 & 0.709606 & 0.00101 & 0.0031 & 0.309 & 0.35 & 2.44 \\
Bd 15 & $3.0 \%$ & 0.00294 & 0.709768 & 0.00123 & 0.0029 & 0.284 & 0.44 & 2.74 \\
Bd 14 & $7.0 \%$ & 0.00308 & 0.712116 & 0.00092 & 0.0035 & 0.318 & 0.92 & 4.54 \\
Bd 12 & $12.8 \%$ & 0.00056 & 0.711049 & 0.00075 & 0.0022 & 0.268 & 0.67 & 4.33 \\
Bun 6 & $20.4 \%$ & 0.00192 & $n . a$. & 0.00121 & 0.0027 & 0.314 & 5.20 & 98.60 \\
OA3 & $18.7 \%$ & 0.00132 & 0.719194 & 0.00136 & 0.0034 & 0.347 & 4.25 & 74.70 \\
OA6 & $5.8 \%$ & $<0.0006$ & n.a. & 0.00060 & 0.0025 & 0.305 & 2.69 & 34.75 \\
OA7 & $4.0 \%$ & $<0.0009$ & 0.710789 & 0.00075 & 0.0032 & 0.372 & 1.88 & 23.84 \\
Pe 9 & $5.2 \%$ & 0.00023 & n.a. & 0.00160 & 0.0031 & 0.342 & 1.13 & 8.97 \\
Pe 7 & $5.0 \%$ & 0.00316 & n.a. & 0.00130 & 0.0036 & 0.305 & 4.23 & 12.40 \\
Pe 3 & $1.0 \%$ & $<0.00010$ & 0.706693 & 0.00621 & 0.0002 & 0.00518 & 0.068 & 0.56 \\
Ba 28 & $5.7 \%$ & $<0.00010$ & 0.707055 & 0.00421 & 0.0001 & 0.00656 & 0.042 & 0.32 \\
Ba 27 & $9.8 \%$ & $<0.00010$ & 0.707200 & 0.00467 & $<0.0001$ & 0.00692 & 0.034 & 0.66 \\
Ba 1 & $4.0 \%$ & $<0.00010$ & 0.706911 & 0.00513 & 0.0003 & 0.00534 & 0.032 & 0.49 \\
Ba 2 & $8.1 \%$ & $<0.00010$ & 0.707252 & 0.00294 & 0.0003 & 0.00634 & 0.169 & 0.49 \\
Ba 13 & $2.4 \%$ & 0.00047 & 0.707006 & 0.00473 & 0.0012 & 0.00659 & 0.036 & 0.32 \\
Ba 14 & $10.5 \%$ & $<0.00010$ & 0.707035 & 0.00363 & $<0.0001$ & 0.00501 & 0.189 & 0.41 \\
& $1.0 \%$ & $<0.00010$ & 0.707219 & 0.00536 & 0.0005 & 0.00860 & 0.044 & 0.17 \\
\hline
\end{tabular}
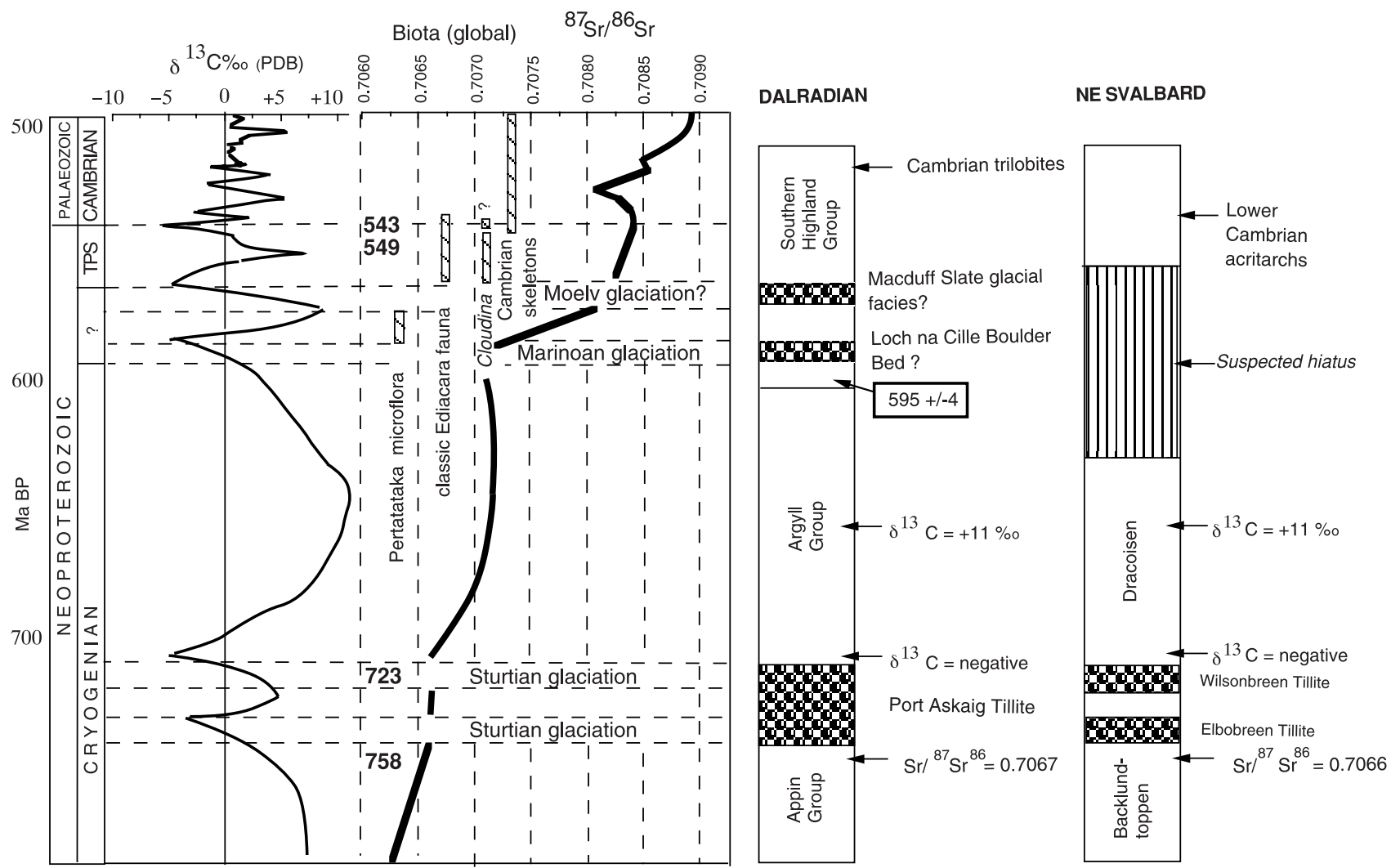

Fig. 2. Carbon and strontium isotopic curves for the Neoproterozoic-Cambrian, based largely on data from SW Mongolia, NW Canada and Oman (from sources cited in the text). Major U-Pb zircon dates shown in bold (from sources in Brasier et al. 2000). At right is shown a suggested time span for the Dalradian and NE Svalbard successions.

the younger, Marinoan/Icebrook and Varanger glaciations (Fig. 2). An older, Sturtian, age for these glaciations is also consistent with a U-Pb zircon date of $595 \mathrm{Ma}$ from the Tayvallich volcanics, and with the inferred presence of glacial deposits higher in the Southern Highland Group (Stoker et al. 1999; Prave 1999a).

We therefore question the commonly held assumption of a younger Varanger/Marinoan age for the twin glaciations of 
NE Svalbard and East Greenland (e.g. Jacobsen \& Kaufman 1999) and agree with Prave (1999a) that these glaciations have Sturtian affinities. If so, then we must also question whether post-Sturtian and post-Marinoan 'cap carbonates' invariably had broadly time-specific lithofacies (i.e., bituminous limestones after Sturtian; dolostones after Marinoan; cf. Kennedy et al. 1998) and caution against the use of 'cap' lithofacies for global chronostratigraphy (cf. Prave 1999b). It seems more likely to us that 'cap' lithofacies and their carbon isotopic profiles were influenced by water depth and regional palaeoceanography.

We thank I. Fairchild for helpful advice in planning the field programme, J. Dewey, A. Brasier and M. Litherland for valuable support in the field. J. Cartledge and $\mathrm{O}$. Green gave assistance in the laboratories at Oxford, and J. Samuel and R. Roualt at the CGS, Strasbourg. We are grateful to I. Fairchild and P. Stille for scientific input. This research was funded by grants from Oxford University, the Academie des Sciences and the CIES.

\section{References}

Anderton, R. 1980. Distinctive pebbles are indicators of Dalradian provenance. Scottish Journal of Geology, 16, 1430-152.

- 1985. Sedimentation and tectonics in the Scottish Dalradian. Scottish Journal of Geology, 21, 407-436.

Brasier, M.D. \& McIlroy, D. 1998. Neonereites uniserialis from c. 600 Ma year old rocks in western Scotland and the emergence of animals. Journal of the Geological Society, London, 155, 5-12.

—, McCarron, G., Tucker, R., Leather, J., Allen, P. \& Shields, G. 2000. $\mathrm{New} \mathrm{U} / \mathrm{Pb}$ zircon dates for Neoproterozoic Gubrah glaciation and for the top of the Huqf Supergroup, Oman. Geology, in press.

—, Shields, G., Kuleshov, V. \& Zhegallo, E.A. 1996. Integrated chemo- and biostratigraphic calibration of early animal evolution: Neoproterozoic - early Cambrian of SW Mongolia. Geological Magazine, 133, 445-485.

Conway Morris, S. 1998. Cloudina from the Dalradian of Scotland: implications for Namibia. In: Palaeontological Society of South Africa. 1998 Conference Programme, 20-1.

Derry, L.A., Kaufman, A.J. \& Jacobsen, S.B. 1992. Sedimentary cycling and environmental change in the Late Proterozoic: evidence from stable and radiogenic isotopes. Geochimica et Cosmochimica Acta, 56, 1317-1329.

—, Keto, L.S., — KNoll, A.H. \& SwetT, K. 1989. Sr isotopic variations in Late Proterozoic carbonates from Svalbard and East Greenland. Geochimica et Cosmochimica Acta, 54, 2331-2339.

Eyles, C.H. \& Eyles, N. 1983. Glaciomarine model for upper Precambrian diamictites of the late Precambrian Port Askaig Formation. Geology, 11, 692-696.

FAIRCHILD, I.J. 1980. Sedimentation and origin of a late Precambrian 'dolomite' from Scotland. Journal of Sedimentary Petrology, 50, 423-446.

- 1985. Petrography and carbonate chemistry of some Dalradian dolomitic metasediments: preservation of diagenetic textures. Journal of the Geological Society, London, 142, 167-185.

— 1989. Dolomitic stromatolite-bearing units with storm deposits from the Vendian of East Greenland and Scotland: a case of facies equivalence. In: GAYER, R.A. (ed.) The Caledonide Geology of Scandinavia. Graham \& Trotman, London, 275-283.
— 1991. Origins of carbonate in Neoproterozoic stromatolites and the identification of modern analogues. Precambrian Research, 53, 281-299.

_ \& Hambrey, M.J. 1995. Vendian basin evolution in East Greenland and NE Svalbard. Precambrian Research, 73, 217.

— \& SpIRo, B. 1987. Petrological and isotopic implications of some contrasting Late Precambrian carbonates, NE Spitsbergen: new insights into the carbonate-tillite association. Geological Magazine, 126, 469-490.

- - Herrington, P.M. \& SonG, T. In press. Controls on $\mathrm{Sr}$ and C isotope compositions of Neoproterozoic Sr-rich limestones of E Greenland and N. China. In: Grotzinger, J. \& JAmes, N.P. (eds) Precambrian carbonates. Society for Sedimentary Geology, Special Publications.

Grotzinger, J.P., Bowring, S.A., SAYlor, B.Z. \& Kaufman, A.J. 1995. Biostratigraphic and geochronologic constraints on early animal evolution. Science, 270, 598-604.

Halliday, A.N., Graham, C.M., Aftalion, M. \& Dymoke, P. 1989. The depositional age of the Dalradian Supergroup: U-Pb and Sm-Nd isotopic studies of the Tayvallich Volcanics, Scotland. Journal of the Geological Society, London, 146, 3-6.

Harris, A.L., Haselock, P.J., Kennedy, M.J. \& Mendum, J.R. 1994. The Dalradian Supergroup in Scotland, Shetland and Ireland. In: GibBons, W. \& HARRIS, A.L. (eds) A revised correlation of Precambrian rocks in the British Isles. Geological Society, London, Special Reports 22, 33-53.

Hoffman, P.F., Kaufman, A.J., Halverson, G.P. \& Schrag, D.P. 1998. A Neoproterozoic snowball earth. Science, 281, 1342-1346.

Jacobsen, S.B. \& Kaufman, A.J. 1999. The Sr, C and O isotopic evolution of Neoproterozoic seawater. Chemical Geology, 161, 37-57.

Kaufman, A.J., Knoll, A.H. \& Narbonne, G.M. 1997. Isotopes, ice ages, and Terminal Proterozoic earth history. Proceedings of the National Academy of Sciences, USA, 94, 6600-6605.

Kennedy, M.J., Runnegar, B., Prave, A.R., Hoffmann, K.-H. \& Arthur, M.A. 1998. Two or four Neoproterozoic glaciations? Geology, 26, 10591063

Knoll, A.H. \& Swett, K. 1987. Micropalaeontology across the PrecambrianCambrian boundary in Spitzbergen. Journal of Palaeontology, 61, 898-926.

— , Hayes, J.M., Kaufman, A.J., Swett, K. \& Lambert, I.B. 1986. Secular variation in carbon isotope ratios from Upper Proterozoic successions of Svalbard and East Greenland. Nature, 321, 832-838.

Prave, A.R. 1999a. The Neoproterozoic Dalradian Supergroup of Scotland: an alternative hypothesis. Geological Magazine, 136, 609-617.

— 1999b. Two diamictites, two cap carbonates, two $\delta^{13} \mathrm{C}$ excursions, two rifts: the Neoproterozoic Kingston Peak Formation, Death Valley, California. Geology, 27, 339-342.

Pringle, J. 1940. The discovery of Cambrian trilobites in the Highland Border rocks near Callander, Perthshire. Report of the British Association for the Advancement of Science, 1, 252.

Saylor, B.Z., Kaufman, A.J., Grotzinger, J.P. \& Urban, F. 1998. A composite reference section for Terminal Proterozoic strata of southern Namibia. Journal of Sedimentary Research, 68, 1223-1235.

Shields, G. 1999. Working towards a new stratigraphic scheme for the Neoproterozoic-Cambrian. Eclogae Geologicae Helvetiae, 92, 221-233.

SOPER, N.J. 1994. Neoproterozoic sedimentation on the northeast margin of Laurentia and the opening of Iapetus. Geological Magazine, 131, 291-299.

Stoker, M.S., Howe, J.A. \& Stoker, S.J. 1999. Late Vendian-?Cambrian glacially influenced deep-water sedimentation, Macduff Slate Formation (Dalradian), NE Scotland. Journal of the Geological Society, London, 156, $55-61$.

TANNER, P.W.G. 1995. New evidence that the Lower Cambrian Leny Limestone at Callander, Perthshire, belongs to the Dalradian Supergroup, and a reassessment of the 'exotic' status of the Highland border Complex. Geological Magazine, 132, 473-483. 